\title{
C9ORF72, the new gene on the block, causes C9FTD/ALS: new insights provided by neuropathology
}

\author{
Eileen H. Bigio
}

Published online: 20 November 2011

(C) Springer-Verlag 2011

New avenues of investigation into sporadic neurodegenerative disease are often revealed by genetic discoveries in familial disease. In frontotemporal dementia, it seems that genetic and molecular discoveries are reported in pairs. MAPT mutations in FTDP-17 with tauopathy (June 1998), PGRN mutations in familial FTLD-U (July 2006), TDP-43 as the major protein component of inclusions in FTLD-U (October 2006) —each of these were reported by different groups in two papers in the same month $[2,3,6,11,18$, 20]. Just 2 months ago, DeJesus et al. [8] and Renton et al. [21] in back-to-back publications in Neuron reported that mutations in a noncoding region of C9ORF72, coding for a protein of unknown function that is highly conserved across species, resulted in expansion of a GGGGCC hexanucleotide repeat, and was the cause of chromosome 9p-linked FTD and ALS. The recommended terminology for FTD and ALS associated with C9ORF72 mutations is C9FTD/ALS [8].

This issue of Acta Neuropathologica continues this pattern, with two articles describing the neuropathology in cases of FTLD-TDP, FTLD-MND, and ALS with C9ORF72 (C9)-expanded repeats $[1,17]$. In the first paper, the Mayo Jacksonville group report clinical and pathologic heterogeneity within a group of 20 cases of C9FTD/ALS [17]. In the second, the Kings College London group compares the neuropathology among 14 C9FTD/ALS cases and 18 FTD/ALS cases without the expanded repeat [1]. The pathology has been previously reported, both in a

\footnotetext{
E. H. Bigio $(\square)$

Division of Neuropathology, Department of Pathology,

Cognitive Neurology and Alzheimer Disease Center,

Northwestern Feinberg School of Medicine, 710 N Fairbanks Ct,

Olson 2-458, Chicago, IL 60611, USA

e-mail: e-bigio@northwestern.edu
}

subset of cases not known to be linked to chromosome 9p, and in cases with known 9p linkage, but the two articles in this issue of Acta Neuropathologica are the first to link specific pathologic findings to cases of C9FTD/ALS [1, 5, 12, 13, 17, 19].

The C9FTD/ALS cases in both papers include cases of FTLD-TDP, FTLD-MND, and ALS. There are fewer FTLD-MND cases in the London group's paper-1 of 14 cases compared to 8 of 20 cases in the Mayo Jacksonville report, but that may simply reflect the difference in how this group determines the final neuropathologic diagnosis, because four of their "ALS/MND" cases have TDP-43 positive inclusions in frontal cortex and dentate gyrus. The Mayo paper sub-typed the FTLD-TDP pathology and interestingly found that some of the C9FTD/ALS cases had Mackenzie type 1 pathology. Because the C9-linked cases reported thus far have been only Mackenzie type 3, the pathology of C9FTD/ALS, therefore, seems to be more heterogeneous than previously thought.

Some of the pathology appears to be unique to C9FTD/ ALS. All 20 of the Mayo Jacksonville and all 14 of the Kings College London cases have ubiquitin + (Mayo) or p62+(Kings)/TDP-43-inclusions in cerebellar granular neurons that are not found in cases without the C9-expanded repeat. The inclusions are predominantly cytoplasmic (CIs), although occasional intranuclear inclusions (NIIs) are also seen. Some inclusions are also present in the molecular layer and in rare Purkinje cells. The Kings College group reported rare TDP-43 positivity of the CIs in one of their 14 cases which the Mayo group did not. The London group had previously described the same inclusions in a subset of TDP cases, which at that time were not known to be C9 positive or linked to chromosome 9, and these appear to have also been positive for ubiquitin $[12,13]$. 
The London group also screened hippocampus and neocortex with p62 and TDP-43. Similar to their previous report, all C9 cases also had abundant unusual "star"shaped inclusions in the hippocampal pyramidal layer, and to a lesser extent in frontal and temporal cortex, along with occasional NIIs in both regions, that were p62 positive and mostly negative for TDP-43 [13]. The Mayo group used ubiquitin on cerebellum, but not on hippocampus or neocortex, and therefore did not report these inclusions. Presumably, the star-shaped inclusions, like the cerebellar inclusions, are also positive with ubiquitin, although it has been reported that p62 is incorporated into inclusions before ubiquitin [15]. In C9 cases, this remains undetermined, since it appears that in their previous report the London group used both p62 and ubiquitin in the cerebellum but only p62 in the hippocampus and cortex [13]. Importantly, the Kings College group previously reported that the star-shaped and cerebellar granular neuron inclusions were negative for neurofilament, alpha-internexin, and FUS, and their current paper adds optineurin and the C9ORF72 protein to this list $[1,13]$.

On the other hand, the Mayo group found fine granular TDP-43 positivity in hippocampal CA2-CA4 regions, which they call "synaptic" labeling, and fine TDP-43 positive neurites predominantly in CA1. Although the Kings College group described very occasional p62 positive dystrophic neurites in the hippocampus in 9 of 14 cases, 5 of which had occasional TDP positivity, it appears that they did not find the same fine neurites in CA1 and synaptic labeling in CA2-4 with TDP-43 immunohistochemistry. This may be due to differences in immunostaining protocols, as TDP-43 results vary greatly, depending mostly on the antigen retrieval methodology.

The p62+/TDP-inclusions in the cerebellar granular layer, hippocampal pyramidal neurons, and neocortex signify that there is an as yet undiscovered protein involved in c9FTD/ALS. Likely suspects, neurofilament, alpha-internexin, and FUS, were previously excluded, and now optineurin and C9ORF72 are also excluded [1, 13]. At the rapid rate new knowledge is currently learned in this field, it will likely soon be identified. What will the identity of this new protein reveal about the molecular process underlying FTLD and ALS? The proteins involved in both ALS and FTLD now include ubiquitin, p62, TDP-43, FUS, ubiquilin2, and VCP. Ubiquitin, ubiquilin2, p62, and VCP are involved in ubiquitin-mediated protein degradation and TDP-43 and FUS bind to DNA, RNA, and protein and are involved in exon skipping, gene and splicing regulation, and transcription repression [7, 10, 14, 16, 18, 22]. Mutations in p62, also known as sequestosome 1, were recently reported in familial and sporadic ALS [9]. While the function of the C9ORF72 protein is unknown, the fact that the mutation is in an intron adds C9FTD/ALS to the class of noncoding repeat expansion disorders that include myotonic dystrophies DM1 and DM2, fragile-X-associated tremor/ataxia syndrome FXTAS, and several spinocerebellar ataxias (SCA8, SCA10, SCA31, SCA36) [8]. Abnormal RNA metabolism has been suggested in both ALS and FTD and the presence of RNA nuclear foci in C9FTD/ALS brains suggests that alternative mRNA splicing is dysregulated. RNA misprocessing may be the underlying mechanism in the pathogenesis of C9FTD/ALS, and understanding this mechanism can lead to new therapeutic targets $[4,8]$. New findings, such as the clinical and pathologic details of C9FTD/ALS presented in the two papers featured in this issue of Acta Neuropathologica, reveal the increasing complexity of the overlap between FTD and ALS [1, 17].

\section{References}

1. Al-Sarraj S, King A, Troakes C, Smith B, Maekawa S, Bodi I, Rogelj B, Al-Chalabi A, Hortobagyi T, Shaw CE (2011) p62 positive, TDP-43 negative, neuronal cytoplasmic and intranuclear inclusions in the cerebellum and hippocampus define the pathology of C9orf72 linked FTLD and MND/ALS. Acta Neuropathol

2. Arai T, Hasegawa M, Akiyama H, Ikeda K, Nonaka T, Mori H, Mann D, Tsuchiya K, Yoshida M, Hashizume Y, Oda T (2006) TDP-43 is a component of ubiquitin-positive tau-negative inclusions in frontotemporal lobar degeneration and amyotrophic lateral sclerosis. Biochem Biophys Res Commun 351:602-611

3. Baker M, Mackenzie IR, Pickering-Brown SM, Gass J, Rademakers R, Lindholm C, Snowden J, Adamson J, Sadovnick AD, Rollinson S, Cannon A, Dwosh E, Neary D, Melquist S, Richardson A, Dickson D, Berger Z, Eriksen J, Robinson T, Zehr C, Dickey CA, Crook R, McGowan E, Mann D, Boeve B, Feldman H, Hutton M (2006) Mutations in progranulin cause tau-negative frontotemporal dementia linked to chromosome 17. Nature 442:916-919

4. Baumer D, Ansorge O, Almeida M, Talbot K (2010) The role of RNA processing in the pathogenesis of motor neuron degeneration. Expert Rev Mol Med 12:e21

5. Boxer AL, Mackenzie IR, Boeve BF, Baker M, Seeley WW, Crook R, Feldman H, Hsiung GY, Rutherford N, Laluz V, Whitwell J, Foti D, McDade E, Molano J, Karydas A, Wojtas A, Goldman J, Mirsky J, Sengdy P, Dearmond S, Miller BL, Rademakers R (2011) J Neurol Neurosurg Psychiatry 82:196-203

6. Cruts M, Gijselinck I, van der Zee J, Engelborghs S, Wils H, Pirici D, Rademakers R, Vandenberghe R, Dermaut B, Martin J-J, van Duijn C, Peeters K, Sciot R, Santens P, De Pooter T, Maria Mattheijssens M, Van den Broeck M, Cuijt I, Vennekens K, De Deyn PP, Kumar-Singh S, Van Broeckhoven C (2006) Null mutations in progranulin cause ubiquitin positive frontotemporal dementia linked to chromosome 17q21. Nature 442:920-924

7. Dai RM, Li CC (2001) Valosin-containing protein is a mutliubiquitin chain-targeting factor required in ubiquitin-proteasome degradation. Nat Cell Biol 3:740-744

8. DeJesus-Hernandez M, Mackenzie IR, Boeve BF, Boxer AL, Baker M, Rutherford NJ, Nicholson AM, Finch NA, Flynn H, Adamson J, Kouri N, Wojtas A, Sengdy P, Hsiung G-YR, Karydas A, Seeley WW, Josephs KA, Coppola G, Geschwind 
DH, Wszolek ZK, Feldman H, Knopman DS, Petersen RC, Miller BL, Dickson DW, Boylan KB, Graff-Radford NR, Rademakers R (2011) Expanded GGGGCC hexanucleotide repeat in non-coding region of C9ORF72 causes chromosome 9p-linked FTD and ALS. Neuron 71:245-256

9. Fecto F, Yan J, Vemula P, Liu E, Yang Y, Chen W, Zheng JG, Shi Y, Siddique N, Arrat H, Donkervoort S, Ajroud-Driss S, Sufit RL, Heller SL, Dang H-X, Siddique T (2011) SQSTM1 mutations in familial and sporadic amyotrophic lateral sclerosis. Arch Neurol 68:1440-1446

10. Hershko A, Ciechanover A, Rose IA (1979) Resolution of the ATP-dependent proteolytic system from reticulocytes: a component that interacts with ATP. Proc Natl Acad Sci USA 76:3107-3110

11. Hutton M, Lendon CL, Rizzu P, Baker M, Froelich S, Houlden H, Pickering-Brown S, Chakraverty S, Isaacs A, Grover A, Hackett J, Adamson J, Lincoln S, Dickson D, Davies P, Petersen RC, Stevens M, de Graaff E, Wauters E, van Baren J, Hillebrand M, Joosse M, Kwon JM, Nowotny P, Che LK, Norton J, Morris JC, Reed LA, Trojanowski J, Basun H, Lannfelt L, Neystat M, Fahn S, Dark F, Tannenberg T, Dodd PR, Hayward N, Kwok JB, Schofield PR, Andreadis A, Snowden J, Craufurd D, Neary D, Owen F, Oostra BA, Hardy J, Goate A, van Swieten J, Mann D, Lynch T, Heutink P (1998) Association of missense and 5'-splicesite mutations in tau with the inherited dementia FTDP-17. Nature 393:702-705

12. King A, Al-Sarraj S, Shaw C (2009) Frontotemporal lobar degeneration with ubiquitinated tau-negative inclusions and additional alpha-synuclein pathology but also unusual cerebellar ubiquitinated p62-positive, TDP-43 negative inclusions. Neuropathol 29:466-471

13. King A, Maekawa S, Bodi I, Troakes C, Al-Sarraj S (2011) Ubiquitinated p62 immunopositive cerebellar cortical neuronal inclusions are evident across the spectrum of TDP-43 proteinopathies but are only rarely additionally immunopositive for phosphorylation-dependent TDP-43. Neuropathology 31:239249

14. Ko HS, Uehara T, Tsuruma K, Nomura Y (2004) Ubiquilin interacts with ubiquitylated proteins and proteasome through its ubiquitin-associated and ubiquitin-like domains. FEBS Lett 566:110-114

15. Kuusisto E, Parkkinen L, Alafuzoff I (2003) Morphogenesis of Lewy bodies: dissimilar incorporation of alphasynuclein, ubiquitin and p62. J Neuropathol Exp Neurol 62:1241-1253

16. Kwiatkowski TJ Jr, Bosco DA, LeClerc AL, Tamrazian E, Vanderburg CR, Russ C, Davis A, Gilchrist J, Kasarskis EJ, Munsat T, Valdmanis P, Rouleau GA, Hosler BA, Cortelli P, de Jong PJ, Yoshinaga Y, Haines JL, Pericak-Vance MA, Yan J,
Ticozzi N, Siddique T, McKenna-Yasek D, Sapp PC, Horvitz HR, Landers JE, Brown RH Jr (2009) Mutations in the FUS/TLS gene on chromosome 16 cause familial amyotrophic lateral sclerosis. Science 323:1205-1208

17. Murray ME, DeJesus-Hernandez M, Rutherford N, Baker M, Duara R, Graff-Radford NR, Wszolek ZK, Ferman T, Josephs KA, Boylan KB, Rademakers R, Dickson DW (2011) Clinical and neuropathologic heterogeneity of c9FTD/ALS associated with hexanucleotide repeat expansion in C9ORF72. Acta Neuropathol

18. Neumann M, Sampathu DM, Kwong LK, Truax AC, Miscenyi MC, Chou TT, Bruce J, Schuck T, Grossman M, Clark CM, McCluskey LF, Miller BL, Masliah E, Mackenzie IR, Feldman H, Feiden W, Kretzschmar HA, Trojanowski JQ, Lee, VM-Y (2006) Ubiquitinated TDP-43 in frontotemporal lobar degeneration and amyotrophic lateral sclerosis. Science 314:130-133

19. Pikkarainen M, Hartikainen P, Alafuzoff I (2008) Neuropathologic features of frontotemporal lobar degeneration with ubiquitin-positive inclusions visualized with ubiquitin-binding protein p62 immunohistochemistry. J Neuropathol Exp Neurol 67:280-298

20. Poorkaj P, Bird TD, Wijsman E, Nemens E, Garruto RM, Anderson L, Andreadis A, Wiederholt WC, Raskind M, Schellenberg GD (1998) Tau is a candidate gene for chromosome 17 frontotemporal dementia. Ann Neurol 43:815-825

21. Renton AE, Majounie E, Waite A, Simon-Sanchez J, Rollinson S, Gibbs JR, Schymick JC, Laaksovirta H, van Swieten JC, Myllykangas L, Kalimo H, Paetau A, Abramzon Y, Remes AM, Kaganovich A, Scholz SW, Duckworth J, Ding J, Harmer DW, Hernandez DG, Johnson JO, Mok K, Ryten M, Trabzuni D, Guerreiro RJ, Orrell RW, Neal J, Murray A, Pearson J, Jansen IE, Sondervan D, Seelaar H, Blake D, Young K, Halliwell N, Callister JB, Toulson G, Richardson A, Gerhard A, Snowden J, Mann D, Neary D, Nalls MA, Peuralinna T, Jansson L, Isoviita V-M, Kaivorinne A-L, Holtta-Vuori M, Ikonen E, Sulkava R, Benatar M, Wuu J, Chio A, Restagno G, Borghero G, Sabatelli M, TheITALSGENConsortium, Heckerman D, Rogaeva E, Zinman L, Rothstein JD, Sendtner M, Drepper C, Eichler EE, Alkan C, Abdullaev Z, Pack SD, Dutra A, Pak E, Hardy J, Singleton A, Williams NM, Heurink P, Pickering-Brown S, Morris HR, Tienari PJ, Traynor BJ (2011) A nexanucleotide repeat expansion in C9ORF72 is the cause of chromosome 9p21-linked ALS-FTD. Neuron 71:257-268

22. Vadlamudi RK, Joung I, Strominger JL, Shin J (1996) p62, a phosphotyrosine-independent ligand of the $\mathrm{SH} 2$ domain of p56lck, belongs to a new class of ubiquitin-binding proteins. J Biol Chem 271:20235-20237 